\title{
Effect of improved home ventilation on asthma control and house dust mite allergen levels
}

Gillian R.Wright, ${ }^{1}$ Stirling Howieson, ${ }^{2}$ Charles McSharry, ${ }^{3}$ Alex D. McMahon, ${ }^{4}$ Rekha Chaudhuri, ${ }^{1}$ Joyce Thompson, ${ }^{6}$ Iona Donnelly, ${ }^{3}$ Richard G. Brooks, ${ }^{7}$ Lisa Jolly, ${ }^{3}$ Lawrence McAlpine, ${ }^{5}$ Eva M. King, ${ }^{8}$ Martin D. Chapman, ${ }^{8}$ Stuart Wood, ${ }^{6}$ Neil C. Thomson. ${ }^{1}$

Departments of Respiratory Medicine ${ }^{1}$ and Immunology, ${ }^{3}$ Division of Immunology, Infection and Inflammation, University of Glasgow, Glasgow, UK. Department of Architecture and Building Science, ${ }^{2}$ University of Strathclyde, Glasgow, UK. Robertson Centre for Biostatistics, ${ }^{4}$ University of Glasgow, Glasgow, UK. Department of Respiratory Medicine, Monklands Hospital, ${ }^{5}$ Airdrie, UK. Section of General Practice, Division of Community-Based Sciences, ${ }^{6}$ University of Glasgow, Glasgow, UK. Department of Economics, University of Strathclyde, Glasgow, UK. ${ }^{7}$ Indoor Biotechnologies, Inc, Charlottesville, US. ${ }^{8}$ 


\section{Address for correspondence and guarantor:}

Professor Neil C. Thomson, Department of Respiratory Medicine, Division of Immunology, Infection and Inflammation, University of Glasgow \& Gartnavel General Hospital, Glasgow, G12 OYN. UK.

Telephone: 44-141-211 $3241 \quad$ Fax: 44-141-211 3464

E-mail: n.c.thomson@clinmed.gla.ac.uk

The Corresponding Author has the right to grant on behalf of all authors and does grant on behalf of all authors, an exclusive licence (or non exclusive for government employees) on a worldwide basis to the BMJ Publishing Group Ltd, and its Licensees to permit this article (if accepted) to be published in BMJ editions and any other BMJPGL products and to exploit all subsidiary rights, as set out in the licence (bmj.com/advice/copyright.shtml)

Word count: 2894

\section{Dedication}

This paper is dedicated to the memory of Dr Stuart Wood, Senior Lecturer in General Practice at the University of Glasgow, who died in March 2006. His kindness, encouragement and enthusiasm for the project are greatly missed. 


\section{ABSTRACT}

\section{Objective}

To determine the effects of improved home ventilation on house dust mite levels and the control of asthma.

\section{Design}

A randomized double-blind placebo-controlled parallel group trial.

\section{Setting}

Participants were recruited from General Practice and Hospital Respiratory Clinics in the West of Scotland.

\section{Participants}

120 adults with asthma who were allergic to house dust mite Dermatophagoides pteronyssinus.

\section{Interventions}

Mechanical heat recovery ventilation (MHRV) units were installed in all homes. Half of the units were activated at randomisation. All homes had carpets steam cleaned and new bedding and mattress covers at baseline.

\section{Main outcome measures}

The primary outcome was morning peak expiratory flow at 12 months. 


\section{Results}

At 12 months, the change in mean morning peak expiratory flow, as compared with baseline, did not differ between the mechanical ventilation group and the control group [mean difference 13.5 liters per minute, 95\% CI. -2.6 to $29.8, \mathrm{p}=0.100$ ]. However, evening mean peak expiratory flow was significantly improved in the mechanical ventilation group [mean difference 24.5 liters per minute, 95\% CI. 8.9 to 40.1, $\mathrm{p}=0.002]$ and there were fewer hospitalizations for asthma ( 0 vs. $4, \mathrm{p}=0.029$ ). Indoor relative humidity was reduced in mechanically ventilated homes, but there was no difference between the groups in Der $\mathrm{p} 1$ levels, compared with baseline, to account for the clinical changes.

\section{Conclusions}

The addition of mechanical heat recovery ventilation to conventional house dust mite eradication strategies did not achieve a reduction in house dust mite levels, but did improve some indices of asthma control.

\section{Trial registration}

ClinicalTrials.gov number NCT00148096

Words count: 252 


\section{INTRODUCTION}

The prevalence of asthma in the western world has increased over the last generation, ${ }^{1}$ in parallel with a warmer indoor microclimate. ${ }^{2}$ Increased insulation, double glazing and modern building construction have improved standards of heating and energy efficiency in homes, but with reduced ventilation. ${ }^{3} \mathrm{~A}$ warm, humid indoor environment favours the growth of the house dust mite population. ${ }^{4}$ Sensitivity to the house dust mite is the most common allergy associated with asthma in the UK. ${ }^{5}$

Studies of occupational asthma ${ }^{6}$ and altitude ${ }^{7}$ infer that the environment may directly affect symptoms of asthma. Accordingly, allergen avoidance has been advocated as an important aspect of asthma management, yet the evidence for its efficacy is limited. ${ }^{8}$ Large studies of conventional measures to eradicate dust mites, such as miteimpermeable mattress covers, have not shown a benefit for asthma symptoms. ${ }^{9,10}$ However, Morgan et $\mathrm{al}^{11}$ found significant improvement in asthma when a number of allergens were targeted in combination with an educational intervention and smoking cessation advice.

As house dust mites thrive in moist conditions, an additional eradication strategy would be to reduce indoor air humidity by improving ventilation. Mechanical heat recovery ventilation is a method of active ventilation using both an extract and a supply fan. Outdoor air is supplied at ambient humidity into the living room and bedroom, and extracted from the kitchen and bathroom. There is evidence that mechanical ventilation reduces indoor air humidity and the house dust mite allergen burden, but the clinical effects on asthma have not been proven. ${ }^{12,13}$ The hypothesis is 
that domestic mechanical heat recovery ventilation, in addition to allergen avoidance measures, can improve asthma control of those sensitive to house dust mite allergen, by attenuating re-colonisation rates.

\section{METHODS}

\section{Participants}

Participants 16 to 60 years of age were eligible if they had asthma for more than one year, were on regular inhaled corticosteroids and had daily symptoms. Participants were recruited from general practice and hospital clinics in Lanarkshire, Scotland, UK. Variable airflow obstruction of $\geq 12 \%$ on spirometry $^{14}$ or $\geq 15 \%$ on peak expiratory flow (PEF) readings ${ }^{15}$ or a symptom score of $\geq 0.86$ on the Asthma Control Questionnaire $(\mathrm{ACQ})^{16,17}$ was required for inclusion. Participants had a minimum forced expiratory volume in 1 second $\left(\mathrm{FEV}_{1}\right)$ of $>50 \%$ predicted at baseline and had not had an exacerbation in the previous month. Spirometric measurements were recorded using an electronic spirometer (Vitalograph, Buckingham, UK), before and after inhaled salbutamol $(400 \mu \mathrm{g}) .{ }^{18}$ PEF measurements were taken at home using a mini-Wright peak flow meter (Clement Clarke, Harlow, UK). Allergy to $D$. pteronyssinus was determined by positive skin prick test, defined as a wheal diameter of $\geq 3 \mathrm{~mm}$ greater than negative control at 15 minutes; solutions supplied by ALK Abello, Hungerford, UK. ${ }^{19}$ Participants were excluded if they were likely to move house or had a pet that provoked their symptoms. Participants were enrolled in the study by the clinical team between April 2003 and November 2005.The Lanarkshire 
Research Ethics Committee approved the study. All participants gave written informed consent.

\section{Study design}

This was a randomised, double-blind, placebo-controlled, parallel group study to evaluate the effect of home installation of mechanical heat recovery ventilation (MHRV), in addition to conventional eradication strategies, in adults with asthma who were sensitive to Dermatophagoides pteronyssinus.

\section{MHRV system}

Homes of eligible participants were surveyed to assess suitability for installation. Homes were excluded if installation was technically difficult or if there was asbestos in ceiling materials. MHRV units (HR250 or HR800) were fitted in the roof space or hallway cupboard in 120 suitable homes by 'Vent-Axia'TM' (Crawley, UK). These energy efficient units extract air continuously from the kitchen and bathroom and deliver pre-warmed air via insulated ducts into the bedroom and living room (Figure 1). The system provided an additional 0.5 air exchanges per hour to the living room and bedroom.

\section{Clinical assessments}

Participants attended a baseline visit where spirometry was recorded and the ACQ ${ }^{16}$ and St. George's Respiratory Questionnaire ${ }^{20}$ were completed. The EQ-5D questionnaire $^{21}$ was used as a standardised generic instrument for valuing healthrelated quality of life. Each score is categorised and 'quality of life years' (QALYs) 
can be calculated from the difference in health states due to an intervention. Participants compiled a 2-week PEF diary prior to the visit. Nasal symptoms were recorded on a visual analogue score. ${ }^{22}$ Serum total $\operatorname{IgE}$ and D. pteronyssinus and pollen-specific IgE were measured by commercial enzyme-immunoassay ${ }^{23}$ (Sweden Diagnostics Ltd, Milton Keynes, UK).

\section{House dust allergen, humidity and other environmental measurements}

The architect team attended the home for a baseline visit. The bedroom, living room floor and bed surface were vacuumed at a rate of $1 \mathrm{~m}^{2}$ per minute to obtain complete dust samples using a Dyson model - DC14 (Dyson, London, UK). The dust samples were filtered and weighed and a standardised soluble extract prepared. The extract concentration of allergens from house dust mite (Der p 1, Der p 2), cat dander (Fel d1) and dog dander (Can f1) were measured using fluorescent multiplex array technology (Indoor Biotechnologies, Charlottesville, VA). ${ }^{24}$ The microbial content of dust was estimated by measuring soluble extract concentrations of bacterial endotoxin and fungal $\beta(1-3)$ glucan (Associates of Cape Cod Inc., East Falmouth, MA, USA). Plasma cotinine was measured using a microplate competitive enzyme immunoassay (Cozart Bioscience Ltd, Abingdon, Oxford, U.K.),

Temperature and humidity were recorded at 90 minute intervals for 12 months in the living room and bedroom using thermohygrographs, 'Gemini Tiny Tag Ultra two channel' dataloggers (Gemini, Chichester, UK). The critical equilibrium humidity, at which no water is gained or lost by the house dust mite, is $73 \%$ relative humidity at $25^{\circ} \mathrm{C} .^{4}$ As maintaining relative humidity below $50 \%$ is a common recommendation 
for reducing dust mites in the home, ${ }^{25}$ the proportion of time that relative humidity fell below $50 \%$ was calculated.

\section{Allergen avoidance measures}

Once baseline measurements were complete, allergen eradication took place in all homes. Carpets were cleaned with a "Medivac" steam cleaner at the rate of $1 \mathrm{~m}^{2}$ per minute (Medivac Healthcare Ltd., Cambridge, UK). New pillows, duvets and mattress covers were supplied to all participants ("Naturelle" range, Medivac Healthcare Ltd., Cambridge, UK).

\section{Randomisation}

Randomisation was performed in sequential blocks of four using an automated telephone answering system at the Robertson Centre for Biostatistics, University of Glasgow, UK, by the architect team. Accordingly, a fused electrical spur was switched in the roof space by the architect to activate half of the units. The unit activation device was concealed from the patient and the clinical research team.

\section{Follow-up}

Participants were followed up at 3, 6, 9 and 12 months after randomisation, until April 2007. Participants measured morning and evening PEF for 2 weeks before each visit. At each visit, spirometry was performed, ACQ score was recorded and requirements for oral corticosteroids, hospitalisations, General Practice or Emergency Department visits were noted. The St. George's Respiratory questionnaire, the EuroQol questionnaire and nasal visual analogue scores and questionnaires were repeated at 6 
and 12 months after randomisation. At 12 months, blood samples for IgE serology, dust samples and humidity measurements were taken and placebo units activated.

\section{Statistical analysis}

The sample size was based upon a parallel group design, using a standard deviation of 40 liters/min for mean morning PEF. The study was intended to have 64 evaluable participants per group $(n=128)$, in order to have $80 \%$ power (at the $5 \%$ significance level) to calculate a difference of 20 liters/min.

The primary analysis was a comparison between groups of the change over baseline in morning PEF. Secondary endpoints were evening PEF, ACQ scores, exacerbation and hospitalisation rates, spirometry, quality-of-life, $\operatorname{Der} p 1$ levels and humidity readings in the homes, IgE levels and economic evaluations. If 12 month data were not available, 9 month data would be used instead. The main analyses were carried out with ANCOVA models adjusted for baseline severity. The analyses were firstly carried out on an intention to treat basis. A list of 'major protocol violators' consisting of those with premature activation by the electrician and randomisation errors was created and the remaining population were denoted the 'per protocol' set. The primary and secondary endpoints were repeated for the 'per protocol' set. Binary endpoints such as hospitalizations were compared by odds-ratios, the attendant $95 \%$ confidence interval and tested by Mantel-Haenszel chi-squared test. 


\section{RESULTS}

\section{Baseline characteristics of participants}

A total of 4986 participants were invited to participate, 482 attended clinical screening and 216 fulfilled the clinical entry criteria (Figure 2). Fifty-three subjects did not fulfill all housing criteria and 43 did not wish to have the MHRV unit installed. Units were installed in 120 homes, 119 underwent randomisation. Baseline demographic characteristics of those randomized were similar (Table 1).

\section{Outcome measures}

\section{Clinical outcomes}

100 participants attended follow-up at 12 months. The clinical outcome measures are listed in Table 2. The change in mean morning PEF did not differ between the MHRV group and the control group [mean difference 13.5 litres per minute, 95\% CI -2.6 to 29.8, $\mathrm{P}=0.100]$. However, there was a significant improvement in the MHRV group compared to the control group in mean evening PEF [mean difference 24.5 litres per minute, $95 \% \mathrm{Cl} 8.9$ to $40.1, \mathrm{P}=0.002$ ] (Figure 3 ).

The ACQ score significantly improved in the MHRV group at 3 months [mean difference, $-0.44,95 \% \mathrm{Cl}-0.76$ to $-0.12, \mathrm{p}=0.008]$, but not thereafter. There were statistically fewer hospitalisations for asthma over the 12 month period in the MHRV group than in the control group ( 0 vs. $4, \mathrm{p}=0.029)$. Values for spirometry, use of rescue medication, St. George's Respiratory Questionnaire score, requirements for oral corticosteroids, General Practitioner or Emergency department visits with asthma 
did not differ between the two groups. Rhinitis visual analogue scores for sneezing, nasal discharge and nasal blockage significantly improved in the MHRV group compared to the control group at 6 months [sneezing, mean difference, -1.07, C.L. 2.05 to $-0.10, \mathrm{p}=0.032$; nasal discharge, mean difference, $-1.36,95 \% \mathrm{Cl}-2.30$ to 0.42, $\mathrm{p}=0.005$; nasal blockage, mean difference, $-1.65,95 \% \mathrm{Cl}-2.74$ to -0.56 , $\mathrm{p}=0.004]$, but not at 12 months. In the economic analysis there was a gain of 0.02 QALYs per MHRV patient. Eighteen major protocol violators were excluded from the 'per protocol' analysis. Fifteen were due to premature activation of the unit by the site electrician and three were randomisation errors. The 'per protocol' analysis confirmed that of the intention-to-treat analysis. Exacerbations of asthma are reported in Table 2 on page 27. No adverse events were reported relating to the installation of the MHRV unit.

\section{Indoor relative humidity and temperature}

MHRV significantly reduced mean relative humidity in the bedrooms for a sustained period from October until February and in the living room from December to February (Figure 4). The median (range) percent of time homes achieved a reduction in the indoor relative humidity below 50\% was greater in the MHRV group than in the control group in the bedroom $[44.1 \%$ (range $6.6 \%$ to $95.5 \%$ ) vs. $28.9 \%$ (range $0.2 \%$ to $81.7 \%$ ), $\mathrm{p}=0.001$ ] but not in the living room [47.0\% (range $9.9 \%$ to $93.3 \%$ ) and $39.5 \%(0.5 \%$ to $83.2 \%), \mathrm{p}=0.256]$. 
Concentration of allergens and microbial products in house dust, and serum IgE levels

At 12 months, the changes in mean Der p 1 and Der p 2 concentrations in the bed, bedroom and living room carpets, as compared with baseline concentrations, did not differ between the MHRV group and the control group, nor were there differences in total or house-dust mite specific IgE. There were also no significant differences in secondary analyses of cat dander allergen (Fel d1), dog dander allergen (Can f1), $\beta$ (13) glucan or endotoxin. (Table 2)

\section{DISCUSSION}

This randomised, double-blind placebo-controlled study examined the effect of the installation of domestic mechanical heat recovery ventilation (MHRV) on asthma control in adults sensitive to house dust mite allergen. It was based on the hypothesis that a warm, humid environment favours growth of the house dust mite population and that decreasing indoor air humidity with mechanical ventilation would reduce the dust mite allergen burden and improve asthma control.

\section{Statement of principal findings}

We found that there were improvements in some indices of asthma control at 12 months: increased evening PEF and fewer hospital admissions with asthma. Indoor relative humidity was reduced in the autumn and winter months in ventilated homes, but there was no difference between Der $\mathrm{p} 1$ levels between the groups to account for the clinical changes. There were improvements in ACQ and Rhinitis visual analogue scores in the MHRV group after 6 months, which were short lasting, and may imply 
that the MHRV intervention was most effective when combined with recent mite eradication strategies.

\section{Strengths and weaknesses of the study}

The strengths of the study are that it was a large community-based randomised trial utilising expertise from different disciplines. Participants reflected the general population with asthma with a GP diagnosis of asthma, daily symptoms and house dust mite sensitivity were sufficient for inclusion. Randomisation was effectively concealed from the participants and the clinical team. As 100 of a projected optimum number of 128 participants completed follow-up, the power of the study may not have been sufficient to detect a significant change in morning PEF.

\section{Relation to previous research}

Two previous small studies have examined the efficacy of MHRV for asthma. Warner and colleagues ${ }^{12}$ showed a non-significant improvement in histamine $\mathrm{PC}_{20}(\mathrm{p}=0.085)$, but no change in lung function or symptom scores with MHRV and high energy vacuum cleaning. $\mathrm{Htut}^{26}$ found a decrease in bronchial hyperreactivity at 12 months after MHRV and steam cleaning. Our study provides weight to the evidence that improved ventilation might have a beneficial effect on asthma control.

Although the Der p 1 and Der p 2 levels fell in both groups, there was no difference between the MHRV group and the control group, adjusted for baseline. There was no difference between the groups in change in serum house-dust mite specific IgE antibody. This suggests that the MHRV system reduced indoor relative humidity to levels that were insufficient to impact on mite levels. Maintaining relative humidity 
below $50 \%$ is a common recommendation for reducing dust mites in the home. ${ }^{25}$ The MHRV unit achieved a relative humidity less than $50 \%$ in the winter months in the bedrooms more frequently than in the control group. However, although it may be statistically significant, it may not be environmentally significant as the fluctuation of humidity levels may permit mite survival. For example, a New Zealand study ${ }^{27}$ showed that, although active ventilation did reduce relative humidity to less than $50 \%$ for 7 months of the year, there were no effects on mite levels because values were below the critical equilibrium humidity for only $39 \%$ of the total of 24 -hour periods for which measurements were made. In another UK study, Fletcher ${ }^{30}$ also found no impact of MHRV on Der p 1. It is possible that 12 months was too short a period to measure a difference in seasonally affected mite re-colonisation rates, after steam cleaning and barrier bedding were implemented across both cohorts.

One reason for this lack of efficacy in mite control may be related to climate. ${ }^{29}$ For ventilation to reduce indoor humidity, the outdoor air humidity must be sufficiently lower than that inside. A Danish study observed 11 subjects with allergic asthma who were moved to 'healthy' homes with MHRV and found that a reduction of indoor absolute humidity was associated with a fall in dust mites and an improvement in indices of asthma control. However, there is an important difference between the cold winters of Scandinavia where the ambient air relative humidity was very low, compared with the high humidity ambient wet air during the milder winters of temperate regions of western Europe and New Zealand. Based on these observations, a future development in the intervention would be a humidistat controller (set at 50\%) linked to a variable flow fan unit to ensure humidity suppression during the colder months. 


\section{Unanswered questions and future research}

As the beneficial clinical effect of MHRV is not explained by a reduction in exposure to house dust mites, which other alternative explanations can be considered? No difference in cat or dog allergens, or in bacterial endotoxin levels in dust samples was demonstrated between the groups. Maintaining relative humidity below $50 \%$ has been recommended for controlling mould. ${ }^{31}$ Burr and co-workers recently conducted an unblinded mold eradication trial that included improved home ventilation and found symptomatic improvement in wheeze, medication use and rhinitis. ${ }^{32}$ In our study no difference between fungal glucan exposure was observed between the groups. Other possible explanations are a reduction in environmental tobacco smoke, respiratory viruses ${ }^{33}$ or another component of indoor air quality such as particulate matter or volatile organic compounds. Increased relative humidity by itself is reported to be sufficient for increasing respiratory and other general symptoms. ${ }^{34,35}$ There appears to be a dose-response relationship between asthma and living in damp housing, with respiratory symptoms more common in subjects living in damp homes. Action to improve damp housing conditions may therefore favourably influence asthma morbidity.

Finally, in the MHRV group there was gain of 0.02 QALY per subject. If the cost of installation is approximately $£ 2000$, the small QALY gain comes at a high price, albeit offset by a small reduction in hospitalisations. However, if the clinical results are sustained for the lifetime of the MHRV unit (10-20 years), the intervention may be more cost-effective. 
In conclusion, this randomised controlled trial has shown clinical benefits of improved home ventilation in asthma control not explained by reduced levels of house dust mites. Future research should determine the mechanism of this effect.

\section{'What this paper adds' box}

\section{What is already known on this subject}

House dust mite allergy is commonly associated with asthma. The warm, humid environment in modern homes favours the house dust mite population. The effect of improved ventilation on asthma control is not known.

\section{What this paper adds}

This randomised controlled trial has shown clinical benefits of improved home ventilation in asthma control. However, this was not explained by reduced levels of house dust mites. Future research should determine the mechanism of this effect. 


\section{Acknowledgements}

The authors are grateful for the initial planning and advice from Professor George Morris from the Scottish Centre for Infection and Environmental Health. They wish to acknowledge the secretarial support of Mrs. Janice Reid and the technical assistance of Mrs. Christine Downie and her staff at Monklands Hospital Respiratory Investigation Centre. They thank Mr Alan Lawson, Mr Robert Gemmel, Mr Paul McBrearty and Mr Denis Dixon as part of the architect study team. They wish to thank the Lanarkshire GPs and practice staff for their help with recruitment, North and South Lanarkshire Councils for arranging asbestos checks and 'Vent-Axia' for their cooperation in planning surveys and installation of MHRV units. They thank the participants and their families for their helpful participation in the study. 


\section{CONFLICT OF INTEREST STATEMENT}

Dr S. Howieson declares that 'Vent-axia TM' provided funding for salaries for technical members of his research team at the University of Strathclyde. All other authors declare that the answers to the questions on the competing interest from are all 'No' and therefore have nothing to declare.

\section{SOURCES OF FUNDING}

The clinical staff and equipment were funded by the Chief Scientist's Office of the Scottish Executive and Greater Glasgow Primary Care NHS Trust. North and South Lanarkshire Councils and 'Communities Scotland' paid for the installation of the MHRV units. Scottish Power, Vent-Axia, EAGA Charitable Trust, Baxi, Transco, Lanarkshire Health Board, Dyson and Energy Action Scotland supported technical staff, barrier bedding, steam cleaning costs, thermohygrographic monitoring and dust sample collection costs.

The research team was independent from these funding bodies.

\section{STUDY SPONSOR}

The Study sponsor was Glasgow Biomedicine. 


\section{REFERENCES}

1. Masoli M, Fabian D, Holt S, Beasley R. Global Burden of Asthma. The Global Initiative for Asthma. 2004. www.ginasthma.org Retrieved 11 November 2007.

2. Platts-Mills T, Vervloet D, Thomas W et al. Indoor allergens and asthma: Report of the Third International Workshop. J Allergy Clin Immunol 1997;100:S1-S24.

3. Burberry P. Ventilation and Air Quality. Environment and Services pp43-55. Longman Scientific and Technical, 1992.

4. Arlian LG. Water balance and humidity requirements of house dust mites. Exp Appl Acarol 1992;16:15-35.

5. Simpson B, Custovic A, Simpson A et al. NAC Manchester Asthma and Allergy Study: risk factors for asthma and allergic disorders. Clin Exp Allergy 2001;31:391399.

6. Papi A, Corbetta L, Fabbri LM. What can we learn from late-onset and occupational asthma? Clin Exp Allergy 1998; 28:174-180.

7. Grootendorst DC, Dahlen SE, van den Bos JW et al. Benefits of high altitude allergen avoidance in atopic adolescents with moderate to severe asthma, over and above treatment with high dose inhaled steroids. Clin Exp Allergy 2001; 31:400-8.

8. British Thoracic Society. Scottish Intercollegiate Guidelines Network. British Guideline on the Management of Asthma. Thorax 2003;58:11-12.

9. Woodcock A, Forster L, Matthews E et al. Control of exposure to mite allergen and allergen-impermeable bed covers for adults with asthma. N Eng J Med 2003;349:22536. 
10. Gøtzsche PC, Johansen HK, Schmidt LM, Burr ML. House dust mite control measures for asthma. Cochrane Database of Systematic Reviews 2004, Issue 4. Art. No.: CD001187. DOI: 10.1002/14651858.CD001187.pub2.

11. Morgan WJ, Crain EF, Gruchalla RS et al. Results of a home-based environmental intervention in urban children with asthma. N Eng J Med 2004;351:1068-80.

12. Warner JA, Frederick JM, Bryant TN et al. Mechanical ventilation and highefficiency vacuum cleaning: A combined strategy of mite and mite allergen reduction in the control of mite-sensitive asthma. J Allergy Clin Immunol 2000;105:75-82.

13. Singh M, Bara A, Gibson P. Humidity control for chronic asthma. Cochrane Database of Systematic Reviews 2002 (2):CD003563.

14. "GINA Report, Global Strategy for Asthma Management and Prevention." 2006 http://www.ginasthma.com/Guideline Retrieved $8^{\text {th }}$ November 2007.

15 Venables KM, Burge PS, Davison AG et al. Peak flow records in surveys: reproducibility of observer's reports. Thorax 1984;39:828-32.

16. Juniper E, O'Byrne P, Guyatt $G$ et al. Development and validation of a questionnaire to measure asthma control. Eur Respir J 1999;14:902-7.

17. Juniper EF, Bousquet J, Abetz L et al. Identifying 'well-controlled' and 'not wellcontrolled' asthma using the Asthma Control Questionnaire. Respir Med 2006;100:616-21.

18. Miller M, Hankinson J, Brusasco V et al. 'ATS/ERS Task force: standardisation of lung function testing'. 2.Standardisation of Spirometry. Eur Respir J 2005;26:319-38.

19. Rusznak C, Davies R. Diagnosing Allergy. BMJ 1998;316:686-9.

20. Jones P, Quirk F, Baveystock C. The St George's Respiratory Questionnaire. Respir Med 1991;85:25-31. 
21. Brooks R with the EuroQol group. EuroQol: the current state of play. Health Policy 2006;37:53-72.

22. Benninger MS, Anon J, Mabry RL. The medical management of rhinosinusitis. Otolarygol Head Neck Surg 1997;117:S41-9

23. Ahlstedt S. Understanding the usefulness of specific IgE blood tests in allergy. Clin Exp Allergy 2002;32:11-6.

24. Earle CD, King EM, Tsay A et al. High-throughput fluorescent multiplex array for indoor allergen exposure assessment. J Allergy Clin Immunol 2007;119:428-33.

25. Arlian LG, Platts-Mills TAE. The biology of dust mites and the remediation of mite allergens in allergic disease. J Allergy Clin Immunol 2001;107:S406-13

26. Htut T, Higenbottam TW, Gill GW et al. Eradication of house dust mite from homes of atopic asthma subjects: a double blind trial. J Allergy Clin Immunol 2001;107:55-60.

27. Crane J, Ellis I, Siebers R et al. A pilot study of the effect of mechanical ventilation and heat exchange on house-dust mites and Der p 1 in New Zealand homes. Allergy 1998;53:755-62.

28. Harving H, Korsgaard J, Dahl R. Clinical efficacy of reduction in house-dust mite exposure in specially designed mechanically ventilated healthy homes. Allergy 1994: 49: 866-70.

29. Colloff MJ. Dust mite control and mechanical ventilation: when the climate is right. Clin Exp Allergy 2005;24:94-6.

30. Fletcher AM, Pickering CAC, Custovic A. Reduction in humidity as a method of controlling mites and mite allergens: the use of mechanical ventilation in British domestic dwellings. Clin Exp Allergy 1996;26:1051-6. 
31. Bush R, Portnoy J. The role and abatement of fungal allergens in allergic disease. J Allergy Clin Immunol 2001;107:S430-40.

32. Burr ML, Matthews IP, Arthur RA et al. The effect on patients with asthma of eradicating visible indoor mould- a randomised controlled trial. Thorax 2007;62:76772

33. Hersoug, L-G. Viruses as the causative agent related to 'dampness' and the missing link between allergen exposure and onset of allergic disease. Indoor Air 2005;15:363-66.

34. Gunnbjörnsdóttir MI, Franklin KA, Norbäck D et al. Prevalence and incidence of respiratory symptoms in relation to indoor dampness: the RHINE study. Thorax. 2006;61:221-5.

35. Williamson IJ, Martin CJ, McGill G et al. Damp housing and asthma: a casecontrol study. Thorax. 1997;52:229-34. 
Table 1. Baseline Demographic and Clinical Characteristics

\begin{tabular}{|c|c|c|}
\hline Characteristic & MHRV Group & Control Group \\
\hline No. of participants & 60 & 59 \\
\hline Age (years) & $41.6( \pm 9.6)$ & $42.3( \pm 10.7)$ \\
\hline $\begin{array}{l}\text { Gender } \\
\text { Female - no. }(\%)\end{array}$ & $41(68.3)$ & $32(54.2)$ \\
\hline $\begin{array}{l}\text { Race or ethnic group }- \text { no. }(\%) \\
\text { Caucasian } \\
\text { Asian }\end{array}$ & $\begin{array}{l}58(96.7) \\
2(3.3)\end{array}$ & $\begin{array}{l}58(98.3) \\
1(1.7) \\
\end{array}$ \\
\hline $\begin{array}{l}\text { Smoking -no. (\%) } \\
\text { Smoker } \\
\text { Ex-smoker } \\
\text { Never smoker }\end{array}$ & $\begin{array}{l}12(20.0) \\
7(11.7) \\
41(68.3)\end{array}$ & $\begin{array}{l}17(28.8) \\
13(22.0) \\
29(49.1)\end{array}$ \\
\hline $\begin{array}{l}\text { Plasma cotinine [all subjects] } \\
\text { ng/ml, median (IQR) }\end{array}$ & $3.4(2.0-63.0)$ & $3.2(2.0-68.0)$ \\
\hline Duration of asthma (years) & $22.1( \pm 14.1)$ & $20.1( \pm 13.9)$ \\
\hline BMI $\left(\mathrm{kg} / \mathrm{m}^{2}\right)$ & $28.4( \pm 5.5)$ & $29.6( \pm 6.3)$ \\
\hline Morning PEF (litres/min) & $414.5( \pm 116.9)$ & $409.1( \pm 91.6)$ \\
\hline Evening PEF (litres/min) & $428.2( \pm 112.4)$ & $426.9( \pm 94.9)$ \\
\hline $\begin{array}{cl}\text { Spirometry (\% predicted) } \\
\text { FEV }_{1} & \text { Prebronchodilator } \\
& \text { Postbronchodilator } \\
\text { FVC } & \text { Prebronchodilator }\end{array}$ & $\begin{array}{l}83.7( \pm 18.0) \\
86.6( \pm 18.1) \\
93.5( \pm 13.6)\end{array}$ & $\begin{array}{l}82.7( \pm 17.7) \\
89.5( \pm 15.6) \\
95.0( \pm 15.4)\end{array}$ \\
\hline $\begin{array}{l}\text { No. of puffs of a short-acting } \\
\beta \text {-agonist (daily) }\end{array}$ & $3.5( \pm 2.5)$ & $4.0( \pm 3.7)$ \\
\hline $\begin{array}{l}\text { Asthma Control } \\
\text { Questionnaire Score } \\
(0 \text { to } 6)\end{array}$ & $2.0( \pm 1.1)$ & $2.0( \pm 1.0)$ \\
\hline $\begin{array}{l}\text { St. George's Questionnaire Score } \\
\text { (0 to } 100 \%)\end{array}$ & $35.3( \pm 23.9)$ & $34.6( \pm 20.4)$ \\
\hline Co-morbidity no. (\%) & & \\
\hline Hypertension & $5(8.3)$ & $8(13.6)$ \\
\hline Previous Myocardial infarction & $0(0.0)$ & $1(1.7)$ \\
\hline Previous Stroke & $1(1.7)$ & $2(3.4)$ \\
\hline Angina & $2(3.3)$ & $3(5.1)$ \\
\hline Diabetes & $3(5.0)$ & $2(3.4)$ \\
\hline Hayfever or other nasal allergy & $44(73.3)$ & $47(79.7)$ \\
\hline Eczema & $15(25.0)$ & $14(23.7)$ \\
\hline Other respiratory & $0(0.0)$ & $1(1.7)$ \\
\hline
\end{tabular}




\begin{tabular}{|c|c|c|}
\hline Characteristic & MHRV Group & Control Group \\
\hline $\begin{array}{l}\text { Inhaled corticosteroid- } \\
\text { beclomethasone equivalent } \\
\mu \mathrm{g} \text {, median (IQR) }\end{array}$ & $1000(800-2000)$ & $800(400-1200)$ \\
\hline \multicolumn{3}{|l|}{ Current other asthma medication } \\
\hline $\begin{array}{l}\text { No. }(\%) \\
\beta_{2} \text {-agonist (short-acting inhaled) } \\
\beta_{2} \text {-agonist (short-acting oral) } \\
\beta_{2} \text {-agonist (long-acting) } \\
\text { Theophylline } \\
\text { Anti-cholinergic } \\
\text { Leukotriene receptor antagonist } \\
\text { Oral steroid }\end{array}$ & $\begin{array}{l}60(100.0) \\
1(1.7) \\
41(68.3) \\
4(6.7) \\
5(8.3) \\
15(25.0) \\
4(6.7)\end{array}$ & $\begin{array}{l}58(98.3) \\
1(1.7) \\
34(57.6) \\
4(6.8) \\
6(10.2) \\
9(15.3) \\
3(5.1)\end{array}$ \\
\hline $\begin{array}{l}\text { Rhinitis visual analogue scale } \\
\text { (1 to } 10 \text { ) } \\
\text { Sneeze } \\
\text { Nasal discharge } \\
\text { Nasal blockage }\end{array}$ & $\begin{array}{l}4.3( \pm 3.1) \\
3.7( \pm 3.1) \\
4.7( \pm 3.0)\end{array}$ & $\begin{array}{l}4.2( \pm 2.7) \\
4.3( \pm 3.1) \\
4.8( \pm 3.1)\end{array}$ \\
\hline $\begin{array}{l}\text { Serum IgE antibody } \\
\mathrm{HDM}\left(\mathrm{kU}_{\mathrm{A}} / \mathrm{L}\right)\end{array}$ & $15.8( \pm 25.8)$ & $20.4( \pm 31.6)$ \\
\hline $\begin{array}{l}\text { Der p } 1 \text { ( } \boldsymbol{\mu g} \text { per gram of dust) } \\
\text { Bed } \\
\text { Bedroom carpet } \\
\text { Living room carpet }\end{array}$ & $\begin{array}{l}4.9( \pm 14.4) \\
3.0( \pm 7.5) \\
2.7( \pm 7.4)\end{array}$ & $\begin{array}{l}2.2( \pm 5.1) \\
1.7( \pm 3.6) \\
3.1( \pm 6.2)\end{array}$ \\
\hline
\end{tabular}

Definition of abbreviations: No., number; Plus-minus values are means \pm Standard Deviation; HDM, house dust mite. 
Table 2. Comparison of clinical outcomes at baseline and 12 months.

\begin{tabular}{|c|c|c|c|c|}
\hline Outcome & $\begin{array}{l}\text { MHRV } \\
(\text { mean } \pm \text { SD })\end{array}$ & $\begin{array}{l}\text { Placebo } \\
(\text { mean } \pm \text { SD })\end{array}$ & $\begin{array}{l}\text { Adjusted difference } \\
\text { ANCOVA }(95 \% \mathrm{Cl})\end{array}$ & p value \\
\hline $\begin{array}{l}\text { PEF am } \\
\text { (litres/min) } \\
\text { Baseline } \\
12 \text { months } \\
\text { Change }\end{array}$ & $\begin{array}{l}414.5 \pm 116.9 \\
419.2 \pm 127.9 \\
6.4 \pm 38.8\end{array}$ & $\begin{array}{l}409.1 \pm 91.6 \\
395.8 \pm 96.0 \\
-7.1 \pm 38.5\end{array}$ & 13.59 (-2.66 to 29.85$)$ & 0.100 \\
\hline $\begin{array}{l}\text { PEF pm } \\
\text { (litres/min) } \\
\text { Baseline } \\
12 \text { months } \\
\text { Change }\end{array}$ & $\begin{array}{l}428.2 \pm 112.4 \\
436.1 \pm 124.7 \\
12.0 \pm 36.4\end{array}$ & $\begin{array}{l}426.9 \pm 94.9 \\
405.9 \pm 93.4 \\
-12.4 \pm 37.9\end{array}$ & $24.56(8.97$ to 40.15$)$ & 0.002 \\
\hline $\begin{array}{l}\text { ACQ } \\
(0-6) \\
\text { Baseline } \\
\text { 12months } \\
\text { Change }\end{array}$ & $\begin{array}{l}2.0 \pm 1.1 \\
1.5 \pm 1.1 \\
-0.4 \pm 0.7\end{array}$ & $\begin{array}{l}2.0 \pm 1.0 \\
1.8 \pm 1.1 \\
-0.1 \pm 1.0\end{array}$ & $-0.25(-0.57$ to 0.08$)$ & 0.141 \\
\hline $\begin{array}{l}\text { Rescue meds } \\
\text { (no. of puffs) } \\
\text { Baseline } \\
12 \text { month } \\
\text { Change }\end{array}$ & $\begin{array}{l}3.5 \pm 2.5 \\
3.5 \pm 2.8 \\
0.0 \pm 1.9\end{array}$ & $\begin{array}{l}4.0 \pm 3.7 \\
3.5 \pm 3.4 \\
0.1 \pm 2.3\end{array}$ & $-0.04(-1.00$ to 0.92$)$ & 0.936 \\
\hline $\begin{array}{l}\text { St George's } \\
(0-100) \\
\text { Baseline } \\
12 \text { months } \\
\text { Change }\end{array}$ & $\begin{array}{l}35.3 \pm 23.0 \\
29.7 \pm 24.4 \\
-5.2 \pm 13.7\end{array}$ & $\begin{array}{l}34.6 \pm 20.4 \\
31.2 \pm 19.9 \\
-2.1 \pm 12.4\end{array}$ & $-2.83(-7.82$ to 2.16$)$ & 0.262 \\
\hline $\begin{array}{l}\mathbf{F E V} \mathbf{1}_{\mathbf{1}} \text { pre } \\
\text { (\% predicted) } \\
\text { Baseline } \\
12 \text { month } \\
\text { Change }\end{array}$ & $\begin{array}{l}83.7 \pm 18.0 \\
86.6 \pm 18.1 \\
1.8 \pm 8.3\end{array}$ & $\begin{array}{l}82.7 \pm 17.7 \\
82.5 \pm 16.9 \\
1.0 \pm 11.3\end{array}$ & $1.32(-2.56$ to 5.19$)$ & 0.502 \\
\hline $\begin{array}{l}\text { Exacerbations } \\
\text { number } \\
\text { Oral steroids } \\
\text { ED visits } \\
\text { GP visits } \\
\text { GP out of hours } \\
\text { Hospitalisations }\end{array}$ & $\begin{array}{l}12 \\
4 \\
0 \\
24 \\
0\end{array}$ & $\begin{array}{l}17 \\
2 \\
1 \\
22 \\
4\end{array}$ & $\begin{array}{l}0.51(0.21-1.22) \\
1.78(0.31-10.16) \\
0.90(0.42-1.93)\end{array}$ & $\begin{array}{l}0.124 \\
0.512 \\
0.282 \\
0.795 \\
\mathbf{0 . 0 2 9}\end{array}$ \\
\hline $\begin{array}{l}\text { Sneezing } \\
\text { VAS } \\
\text { Baseline } \\
6 \text { months } \\
\text { Change } \\
12 \text { months } \\
\text { Change }\end{array}$ & $\begin{array}{l}4.3( \pm 3.1) \\
2.9( \pm 2.4) \\
-1.1( \pm 2.8) \\
2.6( \pm 2.6) \\
-1.7( \pm 3.0)\end{array}$ & $\begin{array}{l}4.2( \pm 2.7) \\
4.1( \pm 2.9) \\
0.0( \pm 2.8) \\
3.1( \pm 2.3) \\
-0.8( \pm 2.3)\end{array}$ & $\begin{array}{l}-1.07(-2.05 \text { to }-0.10) \\
-0.76(-1.70 \text { to } 0.18)\end{array}$ & $\begin{array}{l}\mathbf{0 . 0 3 2} \\
0.111\end{array}$ \\
\hline
\end{tabular}




\begin{tabular}{|c|c|c|c|c|}
\hline \multicolumn{5}{|c|}{ Nasal discharge } \\
\hline Baseline & $3.7( \pm 3.1)$ & $4.3( \pm 3.1)$ & & \\
\hline 6 months & $2.7( \pm 2.7)$ & $4.3( \pm 2.8)$ & & \\
\hline Change & $-0.8( \pm 2.5)$ & $0.4( \pm 2.8)$ & $-1.36(-2.30$ to -0.42$)$ & 0.005 \\
\hline 12 months & $2.7( \pm 2.9)$ & $3.4( \pm 2.4 \mid)$ & & \\
\hline Change & $-0.9( \pm 3.1)$ & $-0.5( \pm 2.7)$ & $-0.46(-0.47$ to 0.55$)$ & 0.371 \\
\hline \multicolumn{5}{|c|}{ Nasal blockage } \\
\hline \multicolumn{5}{|c|}{ VAS } \\
\hline Baseline & $4.7( \pm 3.0)$ & $4.8( \pm 3.1)$ & & \\
\hline 6 months & $3.1( \pm 2.8)$ & $4.3( \pm 2.8)$ & & \\
\hline Change & $-1.3( \pm 2.8)$ & $0.3( \pm 3.2)$ & $-1.65(-2.74$ to -0.56$)$ & 0.004 \\
\hline 12 months & $3.7( \pm 3.0)$ & $4.0( \pm 3.0)$ & & \\
\hline Change & $-0.9( \pm 3.1)$ & $-0.5( \pm 3.2)$ & $-0.51(-1.68$ to 0.66$)$ & 0.392 \\
\hline \multicolumn{5}{|c|}{ Der p $1(\mu \mathrm{g} / \mathrm{g})$} \\
\hline & & & & \\
\hline Baseline & $4.9( \pm 14.4)$ & $2.2( \pm 5.1)$ & & \\
\hline 12 months & $0.7( \pm 1.5)$ & $2.6( \pm 9.6)$ & & \\
\hline Change & $-3.2(-6.7$ to 0.4$)$ & $-1.3(-2.3$ to -0.2$)$ & $-0.32(-0.84$ to 0.21$)$ & 0.232 \\
\hline \multicolumn{5}{|c|}{ Der p 1 $(\mu \mathrm{g} / \mathrm{g})$} \\
\hline Baseline & $2.7( \pm 7.4)$ & $3.1( \pm 6.2)$ & & \\
\hline 12 months & $0.9( \pm 2.0)$ & $1.0( \pm 2.1)$ & & \\
\hline Change & $-1.9(-4.0$ to 0.2$)$ & $-2.8(-4.7$ to -0.9$)$ & $0.1(-0.8$ to 0.9$)$ & 0.850 \\
\hline \multicolumn{5}{|c|}{ Der p $1(\mu \mathrm{g} / \mathrm{g})$} \\
\hline \multicolumn{5}{|c|}{ Bedroom carpet } \\
\hline Baseline & $3.0( \pm 7.5)$ & $1.7( \pm 3.6)$ & & \\
\hline 12 months & $2.3( \pm 11.1)$ & $1.5( \pm 1.8)$ & & \\
\hline Change & $-0.4(-4.7$ to 3.8$)$ & $-0.5(-1.6$ to 0.6$)$ & $1.46(-2.65$ to 5.57$)$ & 0.482 \\
\hline \multicolumn{5}{|c|}{ Der p $2(\mu \mathrm{g} / \mathrm{g})$} \\
\hline Baseline & $1.1( \pm 2.2)$ & $0.9 \pm 2.1$ & & \\
\hline 12 months & $0.3( \pm 0.7)$ & $1.0 \pm 4.0$ & & \\
\hline Change & $-0.6(-1.0$ to -0.3$)$ & $-0.6(-1.0$ to -0.1$)$ & $-0.04(-0.16$ to 0.08$)$ & 0.496 \\
\hline \multicolumn{5}{|c|}{ Der p 2( $(\mu \mathrm{g} / \mathrm{g})$} \\
\hline \multicolumn{5}{|c|}{ Living room } \\
\hline Baseline & $1.2 \pm 3.1$ & $1.4 \pm 3.1$ & & \\
\hline 12 months & $0.9 \pm 3.3$ & $0.5 \pm 1.3$ & & \\
\hline Change & $-0.2(-1.5$ to 1.1$)$ & $-1.3(-2.4$ to -0.2$)$ & $0.56(-0.65$ to 1.77$)$ & 0.359 \\
\hline \multicolumn{5}{|c|}{ Der p $2(\mu \mathrm{g} / \mathrm{g})$} \\
\hline Baseline & $1.7 \pm 3.6$ & $1.0 \pm 2.0$ & & \\
\hline 12 months & $1.6 \pm 7.3$ & $0.9 \pm 1.3$ & & \\
\hline Change & $0.1(-2.4$ to 2.7$)$ & $-0.3(-0.7$ to 0.2$)$ & $1.07(-1.63$ to 3.76$)$ & 0.433 \\
\hline \multicolumn{5}{|c|}{ Cat allergen } \\
\hline Bed & & & & \\
\hline Baseline & $2.9 \pm 5.5$ & $3.3 \pm 0.6$ & & \\
\hline 12 months & $3.3 \pm 5.6$ & $3.4 \pm 0.2$ & & \\
\hline Difference & $0.0(-1.3$ to 1.4$)$ & $0.4(-1.7$ to 2.5$)$ & $-0.29(-2.63$ to 2.06$)$ & 0.809 \\
\hline
\end{tabular}




\begin{tabular}{|c|c|c|c|c|}
\hline $\begin{array}{l}\text { Cat allergen } \\
\text { Living Room } \\
\text { Baseline } \\
12 \text { months } \\
\text { Difference }\end{array}$ & $\begin{array}{l}2.1 \pm 3.8 \\
3.5 \pm 5.9 \\
1.1(-0.5 \text { to } 2.7)\end{array}$ & $\begin{array}{l}2.7 \pm 5.0 \\
4.6 \pm 7.9 \\
2.9(0.8 \text { to } 5.0)\end{array}$ & $-1.81(-4.35$ to 0.73$)$ & 0.161 \\
\hline $\begin{array}{l}\text { Cat allergen } \\
\text { Bedroom carpet } \\
\text { Baseline } \\
12 \text { months } \\
\text { Difference }\end{array}$ & $\begin{array}{l}3.1 \pm 5.4 \\
3.6 \pm 5.1 \\
0.3(-1.1 \text { to } 1.8)\end{array}$ & $\begin{array}{l}4.0 \pm 7.8 \\
3.3 \pm 5.6 \\
-1.1(-3.9 \text { to } 1.7)\end{array}$ & $0.61(-1.59$ to 2.81$)$ & 0.582 \\
\hline $\begin{array}{l}\text { Dog allergen } \\
\text { Bed } \\
\text { Baseline } \\
12 \text { months } \\
\text { Difference }\end{array}$ & $\begin{array}{l}22.2 \pm 41.8 \\
25.4 \pm 56.1 \\
-1.7(-12.1 \text { to } 8.7)\end{array}$ & $\begin{array}{l}21.5 \pm 3.8 \\
11.0 \pm 31.7 \\
-8.4(-23.5 \text { to } 6.7)\end{array}$ & $7.22(-8.64$ to 23.07$)$ & 0.368 \\
\hline $\begin{array}{l}\text { Dog allergen } \\
\text { Living Room } \\
\text { Baseline } \\
12 \text { months } \\
\text { Difference }\end{array}$ & $\begin{array}{l}97.7 \pm 461.4 \\
41.9 \pm 71.9 \\
-67.1(-207.1 \text { to } 73.0)\end{array}$ & $\begin{array}{l}29.8 \pm 50.8 \\
34.8 \pm 53.1 \\
5.8(-11.9 \text { to } 23.4)\end{array}$ & $-3.17(-29.36$ to 23.03$)$ & 0.811 \\
\hline $\begin{array}{l}\text { Dog allergen } \\
\text { Bedroom Carpet } \\
\text { Baseline } \\
12 \text { months } \\
\text { Difference }\end{array}$ & $\begin{array}{l}29.8 \pm 57.9 \\
34.4 \pm 59.1 \\
-1.4(-13.9 \text { to } 11.2)\end{array}$ & $\begin{array}{l}26.2 \pm 54.1 \\
26.2 \pm 4.1 \\
7.2(-6.6 \text { to } 21.1)\end{array}$ & $-5.20(-22.49$ to 12.09$)$ & 0.551 \\
\hline $\begin{array}{l}\text { IgE to HDM } \\
\text { Baseline } \\
12 \text { months } \\
\text { Change }\end{array}$ & $\begin{array}{l}15.8( \pm 25.8) \\
15.5( \pm 24.2) \\
-0.3( \pm 21.7)\end{array}$ & $\begin{array}{l}20.4( \pm 31.6) \\
16.5( \pm 26.1) \\
-3.8( \pm 13.9)\end{array}$ & $2.09(-5.67$ to 9.85$)$ & 0.592 \\
\hline $\begin{array}{l}\text { Mold } \\
\beta(1-3) \text { glucan } \\
\text { Living Room } \\
\text { ( } \mu \text { g/g dust }) \\
\text { Baseline } \\
12 \text { months } \\
\text { Change }\end{array}$ & $\begin{array}{l}322.0( \pm 453.2) \\
108.9( \pm 111.7) \\
-241.6( \pm 486.9)\end{array}$ & $\begin{array}{l}390.8( \pm 582.2) \\
113.4( \pm 37.2) \\
-360.7( \pm 657.0)\end{array}$ & $-7.8(-26.0$ to 10.2$)$ & 0.389 \\
\hline $\begin{array}{l}\text { Mold } \\
\beta(1-3) \text { glucan } \\
\text { Bed }(\mu \mathrm{g} / \mathrm{g} \text { dust }) \\
\text { Baseline } \\
12 \text { months } \\
\text { Change }\end{array}$ & $\begin{array}{l}347.1( \pm 483.3) \\
99.3( \pm 50.8) \\
-273.9( \pm 544.5)\end{array}$ & $\begin{array}{l}255.5( \pm 304.1) \\
77.8( \pm 35.4) \\
-214.3( \pm 366.4)\end{array}$ & $22.7(-0.4$ to 45.9$)$ & 0.055 \\
\hline $\begin{array}{l}\text { Mold } \\
\beta(1-3) \text { glucan } \\
\text { Bedroom carpet } \\
\text { ( } \mu \text { g/g dust) } \\
\text { Baseline } \\
12 \text { months } \\
\text { Change }\end{array}$ & $\begin{array}{l}351.5( \pm 966.6) \\
107.5( \pm 39.4) \\
-270.5( \pm 1063.7)\end{array}$ & $\begin{array}{l}226.9( \pm 216.9) \\
114.2( \pm 64.9) \\
-142.6( \pm 233.8)\end{array}$ & $-15.4(-40.4$ to 9.5$)$ & 0.222 \\
\hline
\end{tabular}




\begin{tabular}{|c|c|c|c|c|}
\hline \multicolumn{5}{|c|}{ Endotoxin (EU) } \\
\hline \multicolumn{5}{|l|}{ Bed } \\
\hline Baseline & $3539( \pm 3213.8)$ & $4479( \pm 3475.9)$ & & \\
\hline 12 months & $4583( \pm 3450.3)$ & $5952( \pm 3617.5)$ & & \\
\hline Change & $1109( \pm 3934.9)$ & $1253( \pm 4969.5)$ & $-1187.5(-2935.7$ to 560.7$)$ & 0.180 \\
\hline \multicolumn{5}{|c|}{ Endotoxin (EU) } \\
\hline \multicolumn{5}{|c|}{ Living Room } \\
\hline Baseline & $5136.2( \pm 2990.8)$ & $6318.4( \pm 2891.1)$ & & \\
\hline 12 months & $7776.9( \pm 2548.9)$ & $6986.0( \pm 2589.9)$ & & \\
\hline Change & $2666.1( \pm 4488.0)$ & $555.6( \pm 4418.9)$ & $497.2(-679.6$ to 1674.1$)$ & 0.403 \\
\hline \multicolumn{5}{|c|}{ Endotoxin (EU) } \\
\hline \multicolumn{5}{|c|}{ Bedroom carpet } \\
\hline Baseline & $5725( \pm 3202.5)$ & $5005( \pm 3438.0)$ & & \\
\hline 12 months & $6996( \pm 3047.0)$ & $6916( \pm 2754.5)$ & & \\
\hline Change & $1148( \pm 4541.9)$ & $1902( \pm 3823.0)$ & $-64.6(-1465.6$ to 1336.28$)$ & 0.927 \\
\hline
\end{tabular}

Definition of abbreviations: Data represented as mean (+/- Standard Deviation), CI confidence interval. Values represent mean difference (CI) compared with baseline. Peak expiratory flow rate $(\mathrm{PEF})$, Forced expiratory volume in 1 second $\left(\mathrm{FEV}_{1}\right)$, Asthma Control Questionnaire (ACQ) score (range, 0 to 6, with higher scores indicating worse asthma control). St. George's Respiratory Questionnaire (range, 0 to 100, with higher scores indicating worse quality of life). ED, Emergency Department, GP, General Practitioner. Rhinitis VAS, visual analogue scale (range, 1 to 10 , with higher scores indicating worse symptoms). Immunoglobulin E (IgE), Dermatophagoides pteronyssinus allergen 1 and 2 (Der p 1 and Der p 2), Endotoxin units (EU) 


\section{FIGURE LEGENDS}

Figure 1. Mechanical heat recovery ventilation system.

The mechanical heat recovery unit extracts air from the kitchen and bathroom (orange ducts) and delivers outdoor air warmed by exchanging heat in baffles with outgoing air via ducts into the bedroom and living room (red ducts). As designed and installed by 'Vent-Axia'TM

\section{Figure 2 Study Profile}

Figure 3 Morning and evening peak expiratory flow measurements at baseline and during follow-up.

(a) At 6 and 12 months, the change in mean morning peak expiratory flow (PEF), as compared with baseline, did not differ between the MHRV group and the control group

(b) At 6 and 12 months, the change in mean evening PEF, as compared with baseline, was significantly greater in the MHRV (mechanical heat recovery ventilation) group compared to the control group [6 months, $\mathrm{P}=0.015$ and at 12 months, $\mathrm{P}=0.002]$.

\section{Figure 4 Relative humidity values and temperature over 12 months}

The fortnightly mean (standard deviation on one-side) relative humidity and temperature in the bedroom and living room show an annual periodicity with the lowest levels in March. MHRV reduced humidity in the bedrooms during April $(* \mathrm{p}<0.05)$ and then for a sustained period from October until February $(\dagger \mathrm{p}<0.001)$. The humidity in the living room was significantly reduced $(* \mathrm{p}<0.05)$ from December to February. There was no effect of MHRV on temperature. 
Figure 1. Mechanical heat recovery ventilation system.

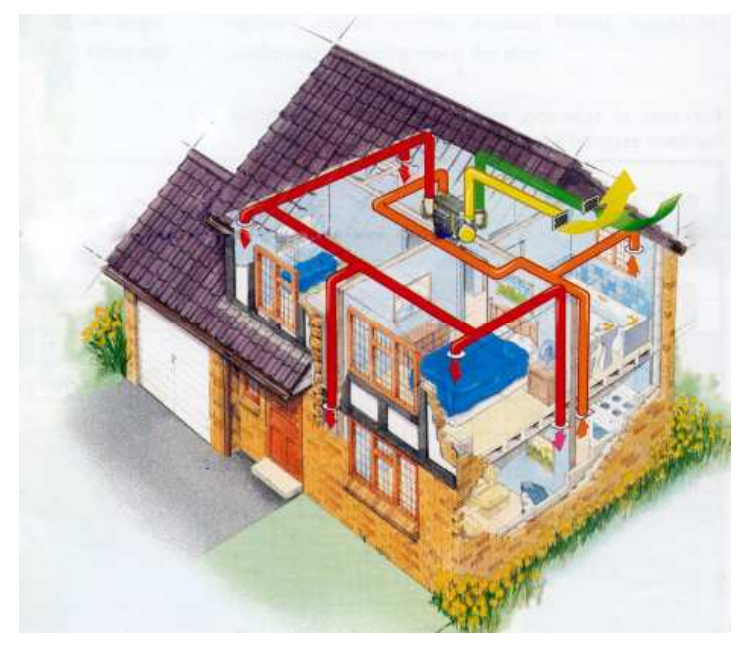


Figure 2 Study profile

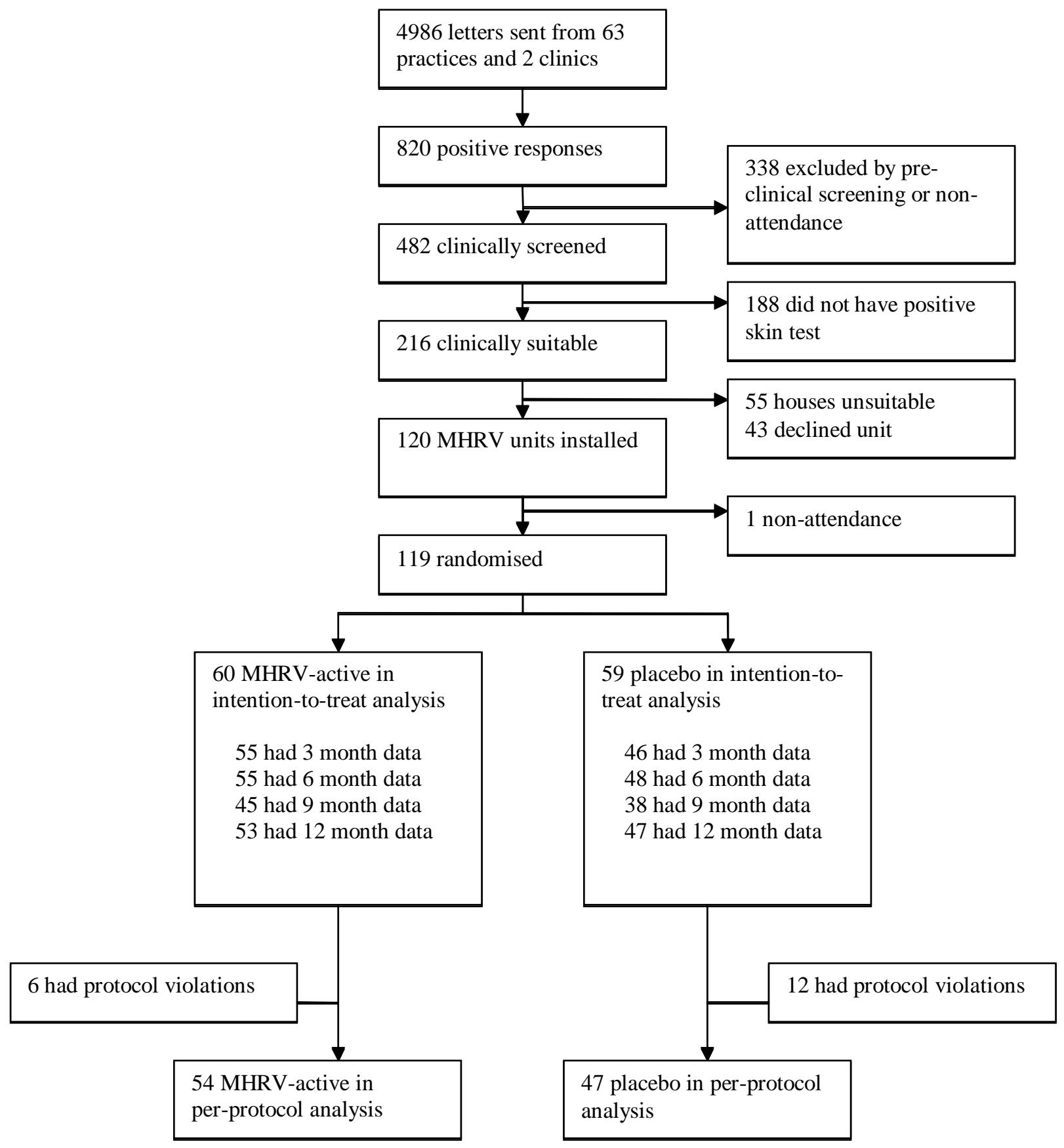


Figure 3 Morning and evening peak expiratory flow at baseline and during follow-up.
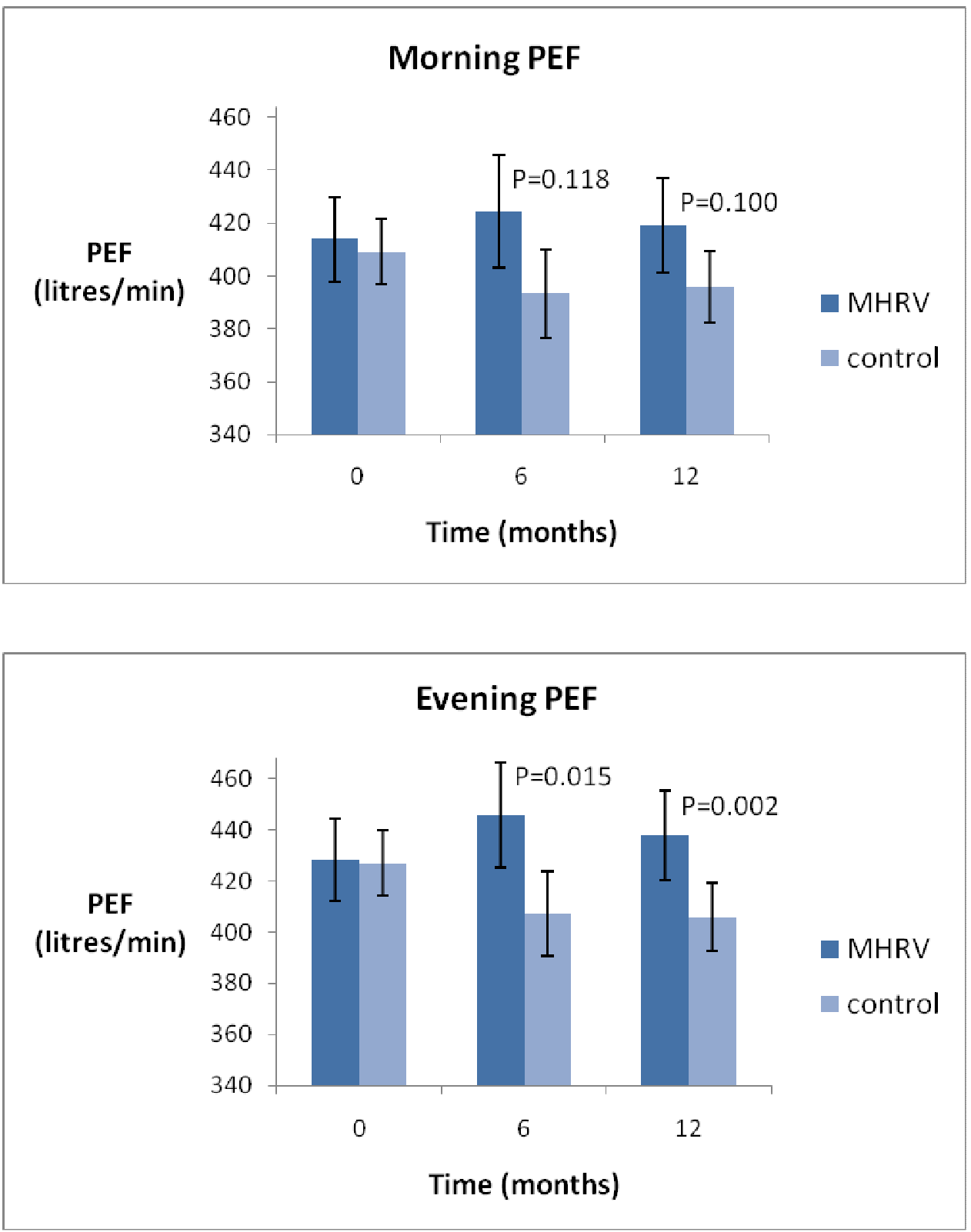
Figure 4 Relative humidity and temperature values over 12 months in MHRV and control groups
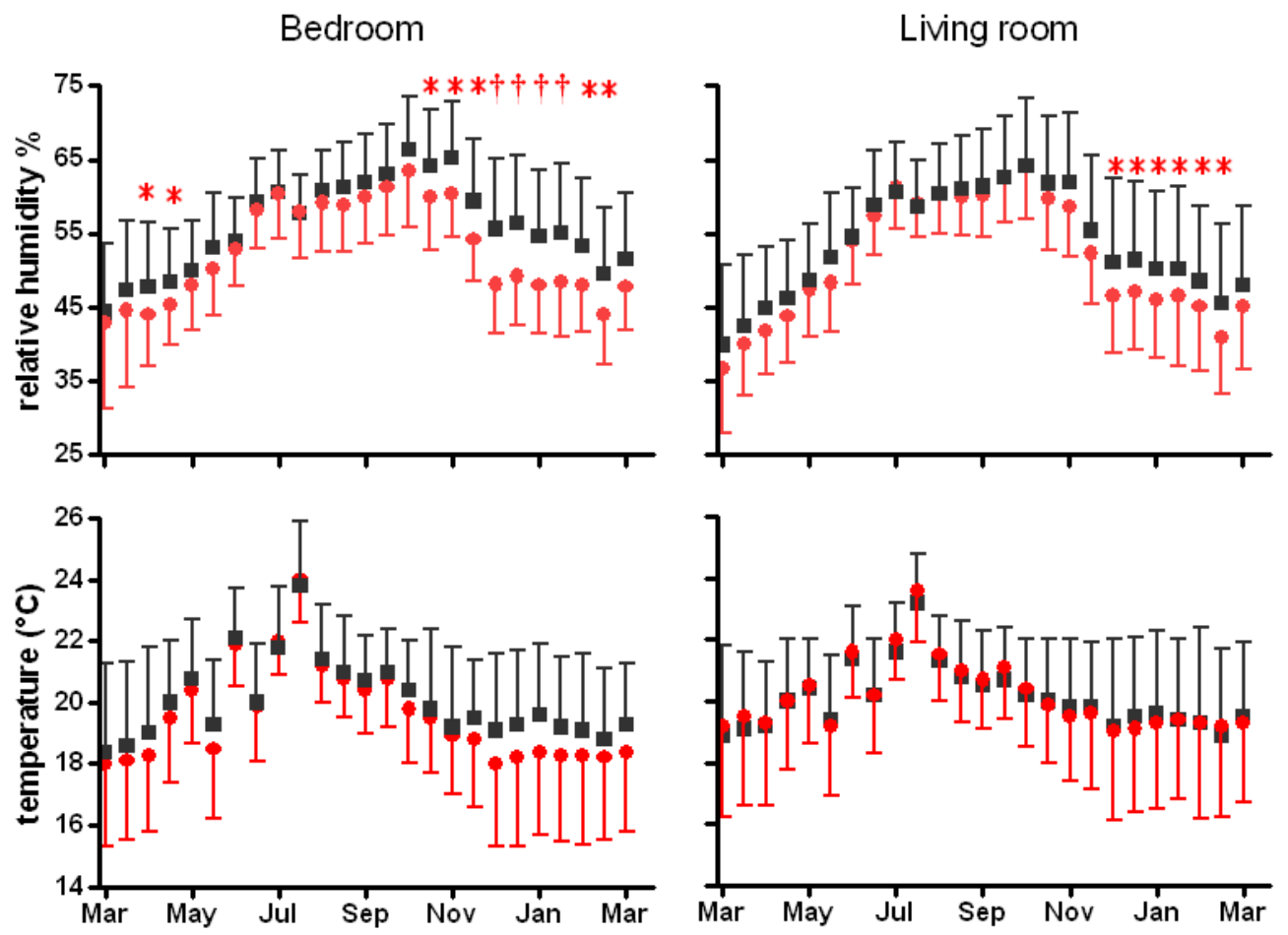